\title{
KOMPETENSI DOSEN DAN PENCAPAIAN HASIL BELAJAR MAHASISWA
}

\author{
Delyana R Pulungan \\ Mutia Arda \\ Fakultas Ekonomi dan Bisnis, Program Studi Manajemen \\ Universitas Muhammadiyah Sumatera Utara \\ e-mail: delyanarahmawany@umsu.ac.id
}

\begin{abstract}
Abstrak
Penelitian ini bertujuan untuk menganalisis bagaimana korelasi kompetensi pedagogik, kompetensi professional, kompetensi kepribadian dan kompetensi social dosen di lingkungan Fakultas Ekonomi dan Bisnis UMSU terhadap pencapaian hasil belajar mahasiswa Fakultas Ekonomi dan Bisnis UMSU. Populasi penelitian ini adalah mahasiswa semester lima Fakultas Ekonomi dan Bisnis UMSU pada prodi Manajemen, Akuntansi, dan Ekonomi Pembangunan. Pemilihan sampel menggunakan teknik cluster dan mengambil sampel 275 mahasiswa. Data yang diperoleh dianalisis menggunakan regresi berganda dengan bantuan SPSS. Hasil analisis diperoleh bahwa kompetensi pedagogik, kompetensi professional, kompetensi kepribadian dan kompetensi social memiliki korelasi positif signifikan terhadap hasil belajar mahasiswa S-1 Fakultas Ekonomi dan Bisnis UMSU. Kompetensi dosen memiliki dampak yang secara nyata dan kuat terhadap perubahan hasil belajar mahasiswa, sehingga semakin baik kompetensi dosen maka akan semakin baik hasil belajar mahasiswa dan sebaliknya jika kompetensi dosen rendah dalam mengajar maka akan berdampak pada rendahnya kualitas hasil belajar mahasiswa.
\end{abstract}

Kata kunci : kompetensi pedagogic, kompetensi professional, kompetensi kepribadian, kompetensi sosial, hasil belajar

\begin{abstract}
His study aims to analyze how the correlation of pedagogic competencies, professional competencies, personality competencies and social competencies of lecturers in the Faculty of Economics and Business UMSU on achieving the learning outcomes of the Faculty of Economics and Business UMSU. The population of this study was the fifth semester students of the Faculty of Economics and Business UMSU in the study program of Management, Accounting, and Development Economics. The sample selection uses cluster techniques and takes a sample of 275 students. The data obtained were analyzed using multiple regression with the help of SPSS. The results of the analysis showed that pedagogic competence, professional competence, personality competence and social competence had a positive and significant correlation to the learning outcomes of students of the Faculty of Economics and Business UMSU. Lecturer competency has a real and strong impact on changes in student learning outcomes, so the better the competence of lecturers, the better student learning outcomes and if lecturer competencies are low in teaching will have an impact on the low quality of student learning outcomes.
\end{abstract}

Keywords : pedagogic competence, professional competence, personality competence, social competence, learning outcomes 


\section{PENDAHULUAN}

Aktivitas pembelajaran merupakan bagian yang sangat penting dalam pelaksanaan pendidikan mulai dari jenjang sekolah dasar hingga perguruan tinggi. Pada kegiatan pembelajaran terjadi transfer ilmu pengetahuan melalui interaksi antara anak didik dengan pendidik atau guru/dosen. Proses transfer ilmu pengetahuan ini sangat diharapkan karena dapat membantu terjadinya perubahan perilaku para peserta didik.

Iskandar (2012) menyatakan bahwa ada beberapa faktor yang mempengaruhi prestasi belajar peserta didik yaitu gaya dosen mengajar, asistensi terhadap mahasiswa, struktur perkuliahan, serta fasilitas yang disertakan dalam proses belajar mengajar. Mahasiswa diketahui lebih tertarik dengan dosen yang memiliki gaya mengajar yang menarik dan tidak membosankan serta tidak menekan mahasiswa sehingga pemahamanan dan tingkat keberhasilan mahasiswa dalam mempelajari matakuliah lebih maksimal. Irianto, (2015) menyebutkan bahwa hasil belajar yang dievaluasi secara teoritis dinilai akan dipengaruhi oleh kompetensi pedagogik, kompetensi professional, kompetensi kepribadian dan kompetensi social seorang dosen. Selain itu didukung oleh Sarbaini, (2017) menyebutkan bahwa profesionalisme dosen berhubungan signifikan terhadap mutu pendidikan. Berdasarkan Permendiknas No. 16/2007 bahwa professional seorang pendidik diukur pada standar umum kualifikasi akademik dan kompetensi yang harus dimilik oleh seorang guru adalah kompetensi pedagogik, kompetensi kepribadian, kompetensi sosial dan kompetensi professional.

Pemenuhan tuntutan para pengguna lulusan yang berkualitas tergambar pada hasil dan prestasi belajarnya yang bergantung pada kompetensi dosen baik kompetensi pedagogik, kompetensi professional, kompetensi kepribadian dan kompetensisosial (Irianto, 2015). Tetapi persoalan yang sering dihadapi adalah perguruan tinggi belum mampu sepenuhnya memenuhi kebutuhan para stakeholder untuk memperoleh sumberdaya manusia atau lulusan yang berkualitas, sehingga masih menjadi predictor terhadap rendahnya pendidikan di Indonesia karena disebabkan oleh beberapa factor yaitu (1) minimnya sarana dan prasarana yang berkualitas (2) rendahnya kualitas pendidik (3) rendahnya kesejahteraan para pendidik (4) rendahnya prestasi para siswa (5) rendahnya kesempatan pemerataan pendidikan (6) rendahnya tingkat korelasi antara pendidikan dengan kebutuhan (7) tingginya biaya pendidikan (Putri \&Suwatno, 2017). Bahkan hasil survey tahun 2011 oleh World Competitivenes, diketahui bahwa tingkat daya saing sumberdaya manusia Indonesia berada pada peringkat 35 dari 59 negara, berada di bawah Thailand pada urutan 26, Malaysia pada urutanke 10 dan Singapura yang berada pada urutan pertama (Sarbaini, 2017).

Kualitas pendidik belum sepenuhnya sesuai dengan kebutuhan yang diharapkan 
Liabilities Jurnal Pendidikan Akuntansi

e-ISSN 2620-5866

Volume 2. No.2 Agustus 2019 (115-124)

Doi. 10.30596/liabilities.v2i2.3288

oleh mahasiswa. Kinerja dosen masih dinilai rendah karena dianggap meja dipenyebab dari rendahnya kualitas anak didik dalam hasil belajar yang dimiliki. maksimal(Ayusri juniantari, 2017). Dosen masih tidak maksimal dalam menyampaikan materi maupun tidak memberikan proses belajar yang menarik sehingga kehadiran mahasiswa tidak maksimal pada matakuliah tertentu, bersikap malas dan dating terlambat dengan sengaja karena menghindari rasa jenuh berada di dalam kelas.

Seorang dosen harus mampu menyampaikan pembelajaran secara menarik, mampu memotivasi mahasiswa aktif dalam mencari pengetahuan, menambah skill dan pengetahuannya, menjadi mitra yang bersinergi dalam bertukar informasi dan melatih untuk memiliki kemampuan berkomunikasi yang baik. Para dosen harus mampu meningtkan daya saing yang positif hingga mahasiswa mampu bersaing di pasar kerja dan tidak menjadi beban social bagi bangsa dan negara. Oleh karena itu kompetensi dosen tidak hanya fokus pada kompetensi keilmuan dan profesionalisme yang dimiliki tetapi juga harus memiliki kompetensi kepribadian dan sosial yang baik, di mana kompetensi ini sering diabaikan atau dianggap tidak terlalu penting.

Penelitian ini dilakukan untuk menganalisis korelasi kompetensi pedagogik, kompetensi professional, kompetensi kepribadian dan kompetensi social dosen di lingkungan Fakultas Ekonomi dan Bisnis UMSU terhadap pencapaian hasil belajar mahasiswa
Fakultas Ekonomi dan Bisnis UMSU.

\section{METODE}

Penelitian ini menggunakan pendekatan action research yang menggabungkan penelitian kuantitatif dengan kualitatif yang menguji pengaruh kompetensi dosen terhadap hasil belajar mahasiswa Fakultas Ekonomi dan Bisnis UMSU.

Populasi penelitian ini adalah mahasiswa Fakultas Ekonomi dan Bisnis UMSU yang berada pada jenjang semester 5 tahun ajaran 2018/2019. Pemilihan populasi berdasarkan pengetahuan mahasiswa semester 5 yang dianggap lebih mengenal dan mengetahui kompetensi dosen Fakultas Ekonomi dan Bisnis

UMSU. Total sampel mahasiswa FEB UMSU semester 5 adalah 275 yang dipilih menggunakan teknik proporsional cluster sampling. Secara proporsi setiap program studi Manajemen, Akuntansi dan Ekonomi Pembangunan diperoleh jumlah mahasiswa sebagai berikut:

\begin{tabular}{|c|l|c|c|}
\hline NO. & \multicolumn{1}{|c|}{ PRODI } & $\begin{array}{c}\text { JUMLAH } \\
\text { MAHASISWA }\end{array}$ & SAMPEL \\
\hline 1 & Manajemen & 488 orang & 152 orang \\
\hline 2 & Akuntansi & 367 orang & 114 orang \\
\hline 3 & $\begin{array}{l}\text { Ekonomi } \\
\text { Pembangunan }\end{array}$ & 28 orang & 9 orang \\
\hline & Total & 883 orang & 275 orang \\
\hline
\end{tabular}

Data diperoleh dengan menggunakan teknik kuesioner dan sekaligus wawancara terhadap mahasiswa. Teknik analisis data yang digunakan adalah regresi linier berganda dengan menggunakan SPSS. 


\section{HASIL DAN PEMBAHASAN}

\section{A. Statistik Deskriptif Responden}

Analisis ini dilakukan untuk melihat profil responden penelitian ini yang dikriteri akan menjadi beberapa golongan yaitu:

1. Profil responden berdasarkan program studi

Responden penelitian ini lebih banyak adalah mahasiswa yang melakukan studi pada program studi manajemen yaitu $(55,27 \%)$, kemudian ada $41,45 \%$ sebagai mahasiswa prodi akuntansi dan sisanya adalah mahasiswa ekonomi pembangunan (3,27\%). Maka diketahui bahwa mahasiswa manajemen adalah mahasiswa yang paling banyak jumlahnya di Fakultas Ekonomi dan Bisnis UMSU.

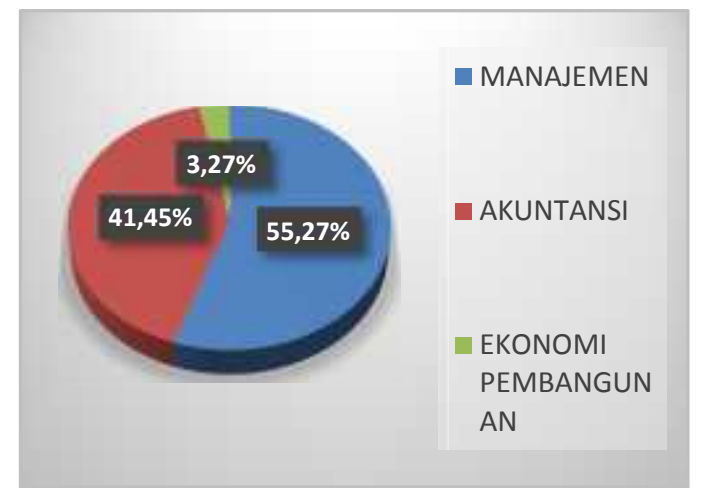

Gambar 1.

Demografi Responden Berdasarkan Program Studi

2. Profil respoden berdasarkan jenis kelamin

Gambaran ini merupakan deskripsi tentang jenis kelamin responden penelitian, yaitu:

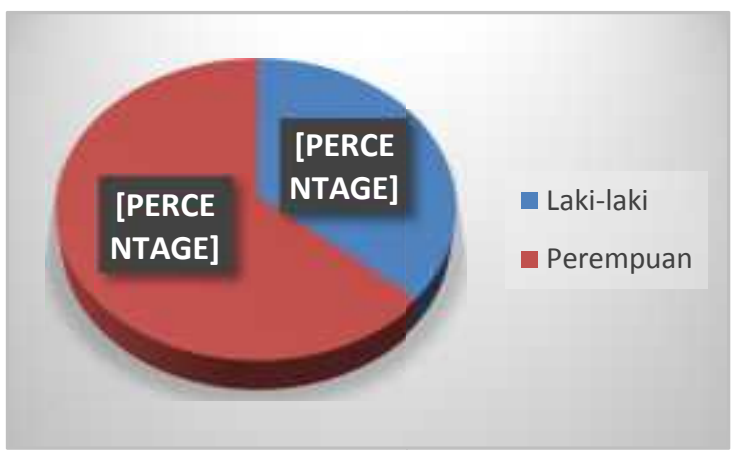

Gambar 2.

Demografi Responden

Berdasarkan Jenis Kelamin

Grafik menggambarkan bahwa mayoritas responden penelitian adalah perempuan yaitu 53\% sedangkan sisanya adalah mahasiswa laki-laki yaitu $47 \%$.

3. Profil responden berdasarkan hasil belajar

Berdasarkan hasil belajar maka diketahui profil responden penelitian adalah:

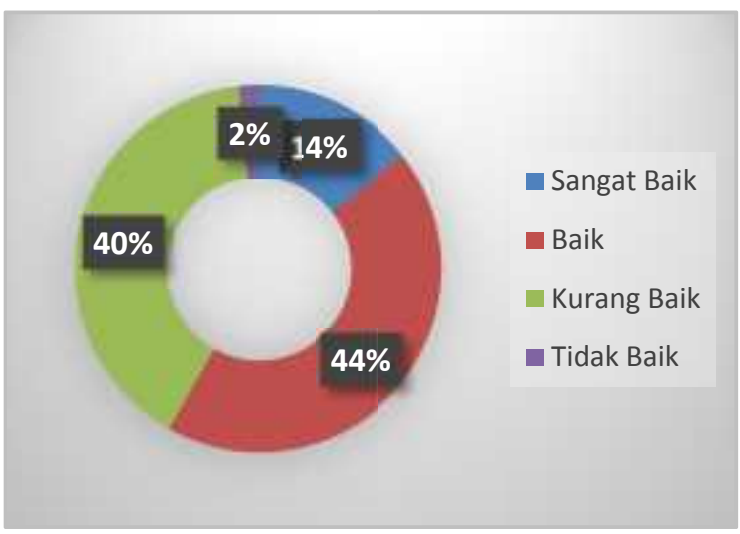

Gambar 3.

Demografi Responden

Berdasarkan Hasil Belajar

Grafik menggambarkan bahwa mahasiswa lebih banyak berada pada tingkat hasil belajar yang baik (44\%), kurang baik (40\%), sangat baik (14\%) dan sisanya tidak baik (2\%). Mahasiswa FEB UMSU 
Liabilities Jurnal Pendidikan Akuntansi e-ISSN 2620-5866

Volume 2. No.2 Agustus 2019 (115-124)

Doi. 10.30596/liabilities.v2i2.3288

masih masuk dalam kategori yang dinilai memiliki hasil belajar baik dan cukup seimbang dengan jumlah mahasiswa yang memiliki hasil belajar kurang baik.

4. Profil responden berdasarkan tingkat kepuasan mahasiswa terhadap kompetensi dosen

Kepuasan mahasiswa juga menjadi ketagori yang dipilih untuk melihat profil mereka sebagai responden, dan hasilnya adalah:

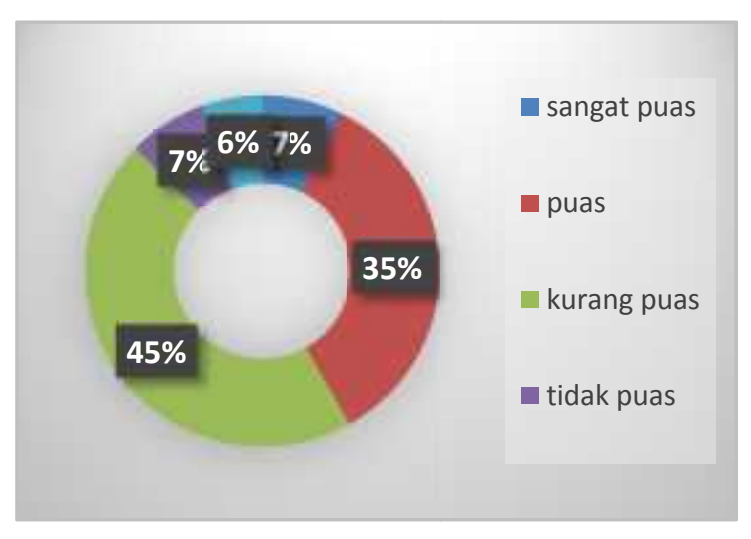

Gambar 4.

Demografi Responden Berdasarkan Tingkat Kepuasan Mahasiswa Terhadap Kompetensi Dosen

Grafik menggambarkan hasil tingkat kepuasan mahasiswa terhadap kompetensi dosen bahwa $45 \%$ mahasiswa menyatakan kurang puas dengan kemampuan dosen dalam mengajar atau dalam menjalankan tugas dan tanggungjawabnya sebagai dosen. Ada 35\% mahasiswa menyatakan rasa puas, $7 \%$ menyatakan puas, $7 \%$ menyatakan tidak puas dan sisanya $6 \%$ menyatakan sangat tidak puas terhadap kompetensi dosen mengajar. Kondisi ini mengindikasikan bahwa mayoritas mahasiswa FEB UMSU merasa kurang puas dengan kemampuan dosen dalam mengajar (pedagogic, professional, kepribadian, dan sosial) sehingga dianggap memberikan kontribusi dan berdampak pada hasil belajar mahasiswa yang baik (44\%) dengan kurang baik (40\%) berimbang jumlahnya.

\section{B. Profil Kompetensi Dosen dan Hasil BelajarMahasiswa}

Kompetensi pedagogic dosen FEB UMSU masuk dalam kategori yang kurang baik dengan nilai 3,07. Dosen FEB UMSU dinilai tidak memiliki kompetensi yang baik dalam menyampaikan materi pembelajaran kepada mahasiswa, karena tidak melaksanakan pembelajaran sesuai rencana pembelajaran. Dosen juga dinilai tidak mampu memanfaatkan teknologi infromasi/komunikasi dalam proses pembelajaran di kelas. Tetapi mahasiswa masih memberikan penilaian yang baik terhadap kemampuan dosen untuk mengembangkan peserta didik agar mampu mengaktualisasi berbagai potensi yang dimilikinya. Dosen juga dinilai baik dalam memfasilitasi pengembangan potensi peserta didik.

Kompetensi professional dosen FEB UMSU masuk dalam kategori yang baik dengan nilai 3,69. Mahasiswa S-1 FEB UMSU Medan memberikan penilaian yang baik terhadap kemampuan dosen dalam menjelaskan seluruh pokok bahasan materi pembelajaran secara tepat mampu memberikan contoh yang relavan pada saat mengajar yang disesuiakan dengan materi, menguasai standar 
kompetensi mata pelajaran yang diampu. Tetapi mahasiswa menilai kurang baik terhadap kompetensi dosen dalam menggunakan beragai ragam teknologi sehingga dianggap tidak menguasai atau tidak mengikuti perkembangan isu mutakhir sesuai bidang ilmu yang diajarkan.

Kompetensi kepribadian dosen FEB UMSU masuk dalam kategori yang baik dengan nilai 3,56. Mahasiswa S-1 FEB UMSU Medan menilai bahwa secara keseluruhan bahwa dosen FEB UMSU memiliki kepribadian yang baik yang dinilai cukup berwibawa sebagai dosen, dianggap arif dalam mengambil keputusan, mampu mengendalikan diri, memiliki etos kerja dan tanggungjawab yang tinggi dalam menjalankan perannya sebagai dosen di FEB UMSU Medan. Tetapi dosen FEB UMSU dinilai kurang baik dalam memberikan contoh teladan dalam berperilaku dan dianggap tidak adil dalam memperlakukan mahasiswa sehingga dinilai tidak objektif dan bersikap diskriminatif terhadap mahasiswa.

Kompetensi social dosen FEB UMSU masuk dalam kategori yang baik dengan nilai 3,41. Mahasiswa S-1 FEB UMSU Medan menilai bahwa secara keseluruhan bahwa dosen FEB UMSU memiliki kepribadian yang baik dan kehidupan sosial yang baik, mampu bersosialisasi dan berkomunikasi yang baik dengan lingkungan disekitarnya termasuk mahasiswa. Rata-rata hasil belajar mahasiswa FEB UMSU Medan masuk dalam kategori kurang baik dengan nilai 3,21. Mayoritas mahasiswa
FEB UMSU memiliki IPK pada saat semester 5 TA. 2018/2019 (masa penelitian ini dilakukan) $>2,75-3,50$ yaitu sebanyak 120 orang.

\section{Analisis Multiple Regression}

Dalam penelitian ini terdapat 4 variabel independen, yaitu kompetensi pedagogik, kompetensi professional, kompetensi kepribadian dan kompetensi social serta satu variable dependen yaitu hasil belajar mahasiswa. Adapun rumus dari regresi linear berganda adalah sebagai berikut :

$Y=a+b^{\wedge} 1 X^{\wedge} 1+b^{\wedge} 2 X^{\wedge} 2+b^{\wedge} 3 X^{\wedge} 3+b^{\wedge} 4$ $\mathrm{X}^{\wedge} 4+\mathrm{e}$

\section{Tabel 1. Uji AnalisisRegresi Linear Berganda}

\begin{tabular}{|c|c|c|c|c|c|}
\hline \multicolumn{6}{|c|}{ Coefficients $^{\mathrm{a}}$} \\
\hline \multirow[t]{2}{*}{ Model } & \multicolumn{2}{|c|}{$\begin{array}{l}\text { Unstandardized } \\
\text { Coefficients }\end{array}$} & \multirow{2}{*}{$\begin{array}{c}\text { Standardize } \\
\mathrm{d} \\
\text { Coefficients } \\
\text { Beta }\end{array}$} & \multirow[t]{2}{*}{$\mathrm{t}$} & \multirow[t]{2}{*}{ Sig. } \\
\hline & B & Std. Error & & & \\
\hline (Constant) & ,819 &, 872 & & 1,503 &, 136 \\
\hline $\begin{array}{c}\text { Kompetensi } \\
\text { Pedagogik }\end{array}$ & ,425 &, 117 & ,319 & 3,631 &, 000 \\
\hline $\begin{array}{l}\text { Kompetensi } \\
\text { Professional }\end{array}$ & ,894 &, 176 & ,447 & 5,090 &, 000 \\
\hline $\begin{array}{l}\text { Kompetensi } \\
\text { Kepribadian }\end{array}$ & .597 & .113 & .745 & 5.295 & .009 \\
\hline $\begin{array}{c}\text { Kompetensi } \\
\text { Sosial }\end{array}$ & 610 & .135 & .644 & 4.527 & .003 \\
\hline
\end{tabular}

a.Dependent Variable: Hasil Belajar

Sumber : Hasil Pengolahan Data (2019)

Hasil uji berikutnya adalah hasil uji simultan yang terlihat pada Tabel2. 
Liabilities Jurnal Pendidikan Akuntansi

e-ISSN 2620-5866

Volume 2. No.2 Agustus 2019 (115-124)

Doi. 10.30596/liabilities.v2i2.3288
Tabel 2. Hasil Uji Simultan ANOVA $^{\text {b }}$

\begin{tabular}{|l|r|r|r|r|r|}
\hline Model & $\begin{array}{c}\text { Sum of } \\
\text { Squares }\end{array}$ & \multicolumn{1}{c|}{$\begin{array}{c}\text { Mean } \\
\text { Sf }\end{array}$} & \multicolumn{1}{|c|}{ e } & \multicolumn{1}{|c|}{$\mathrm{F}$} & Sig. \\
\hline $\begin{array}{l}\text { 1 Regressi } \\
\text { on }\end{array}$ & 71,965 & 2 & 23,988 & 114,59 &, $000^{\mathrm{a}}$ \\
Residual & 61,963 & 27 & 209 & & \\
& 2 & & & \\
Total & 133,928 & 27 & & & \\
\hline
\end{tabular}

a. Predictors: (Constant), Kompetensi pedagogik, kompetensi professional, kompetensi kepribadian, kompetensi nasional

b. Dependent Variable: Hasil belajar mahasiswa

Sumber : Hasil Pengolahan Data (2019)

Hasil pengujian simultan diketahui seluruh variable kompetensi dosen (kompetensi pedagogik, kompetensi professional, kompetensi kepribadian dan kompetensi sosial) memiliki pengaruh yang kuat dan secara nyata berbanding lurus terhadap hasil belajar mahasiswa S-1 Fakultas Ekonomi dan Bisnis UMSU yaitu semakin baik kompetensi dosen maka akan berdampak pada semakin baik hasil belajar mahasiswa S-1 Fakultas Ekonomi dan Bisnis UMSU.

Kemudian dilakukan uji determinasi untuk melihat besar pengaruh kompetensi pedagogik, kompetensi professional, kompetensi kepribadian dan kompetensi social dalam menerangkan hasil belajar mahasiswa FEB UMSU.

Tabel 3. Uji Determinasi Model Summary

\begin{tabular}{l|c|r|r|r|}
\hline Model & $\mathrm{R}$ & $\begin{array}{r}\mathrm{R} \\
\text { Square }\end{array}$ & $\begin{array}{r}\text { Adjusted } \\
\mathrm{R} \text { Square }\end{array}$ & $\begin{array}{c}\text { Std. Error } \\
\text { of the } \\
\text { Estimate }\end{array}$ \\
\hline 1 &, $733^{\mathrm{a}}$ &, 537 &, 533 & .45753 \\
\hline
\end{tabular} $\begin{aligned} & \text { a. Predictors: (Constant), Kompetensipedagogik, } \\
& \text { kompetensi professional, } \\
& \text { npetensikepribadian, kompetensinasional } \\
& \text { b. Dependent Variable: Hasil belajarmahasiswa }\end{aligned}$

Hasil uji determinasi memperlihatkan bahwa variable independen (kompetensi pedagogik, kompetensi professional, kompetensi kepribadian dan kompetensi sosial) dapat menerangkan variabilitas hanya sebesar 53,3\% dari variable dependen (hasil belajar mahasiswa S-1 Fakultas Ekonomi dan Bisnis UMSU), sedangkan sisanya $46,7 \%$ diterangkan oleh variabel lain yang tidak diteliti dalam penelitian ini.

\section{Korelasi Kompetensi Pedagogik Dosen} Terhadap Hasil Belajar Mahasiswa Fakultas Ekonomi Dan Bisnis UMSU.

Kompetensi pedagogic dosen FEB UMSU memiliki hubungan yang positif signifikan terhadap hasil belajar mahasiswa S-1 FEB UMSU Medan. Kompetensi pedagogic dosen terbukti mampu memberikan hasil yang nyata dan kuat terhadap hasil belajar mahasiswa. Ada hubungan yang positif yaitu semakin baik kompetensi pedagogic yang dimiliki dosen maka akan memberikan hasil belajar yang baik pada mahasiswa. Penelitian ini sejalan dengan penelitian yang dilakukan oleh Irianto (2015), yaitu kompetensi pedagogic dosen berpengaruh terhadap hasil belajar mahasiswa.

\section{Korelasi Kompetensi Professional Dosen Terhadap Hasil Belajar Mahasiswa Fakultas Ekonomi Dan Bisnis UMSU}

Kompetensi professional dosen FEB UMSU terbukti memiliki hubungan yang positif signifikan terhadap hasil belajar mahasiswa S-1 FEB UMSU Medan. Kompetensi professional dosen terbukti mampu memberikan pengaruh yang nyata 
dan kuat terhadap hasil belajar mahasiswa. Adanya hubungan positif memperlihatkan hubungan yang berbanding lurus antara kompetensi professional dengan hasil belajar mahasiswa yaitu semakin baik kompetensi professional dosen maka akan semakin mampu memberikan hasil belajar yang baik pada mahasiswa. Hasil penelitian ini sesuai dengan penelitian yang dilakukan oleh (Irianto, 2015) bahwa kompetensi professional berpengaruh terhadap hasil belajar mahasiswa.

\section{Korelasi Kompetensi Kepribadian Dosen Terhadap Hasil Belajar Mahasiswa Fakultas Ekonomi Dan Bisnis UMSU}

Kompetensi kepribadian dinyatakan memiliki pengaruh yang kuat dan secara nyata memberikan dampak yang kuat terhadap hasil belajar mahasiswa S-1 FEB UMSU Medan. Hubungan pengaruh antara kompetensi kepribadian dengan hasil belajar mahasiswa adalah hubungan positif yaitu semakin baik kompetensi kepribadian yang dimiliki oleh dosen FEB UMSU maka akan memberikan dampak positif juga terhadap peningkatan hasil belajar mahasiswa, sedangkan jika dosen memiliki kompetensi kepribadian yang tidak baik maka akan berdampak pada hasil belaja rmahasiswa menjadi tidak baik. Hasil penelitian ini sejalan dengan penelitian (Ayusrijuniantari, 2017; Irianto, 2015) yaitu kompetensi kepribadian dosen memiliki hubungan yang positif meskipun tidak memiliki dampak yang kuat dan nyata terhadap hasil belajar mahasiswa S-1 FEB UMSU Medan. Guru atau dosen dituntut untuk memiliki kompetensi berupa pengetahuan, perilaku dan keterampilan untuk mencapai tujuan pembelajaran di mana kompetensi yang dimiliki harus merupakan perpaduan antara kemampuan personal, keilmuan, teknologi, sosial dan spiritual yang menjadi standar kompetensi seorang pendidik dalam bergaul atau berkomunikasi dengan peserta didiknya. Guru juga diminta memiliki kemampuan berkomunikasi dengan sesame pendidik, tenaga kependidikan, orang tua/walipeserta didik maupun masyarakat sosial di sekitarnya. (Ayusri juniantari, 2017).

\section{Korelasi Kompetensi Sosial Dosen Terhadap Hasil Belajar Mahasiswa Fakultas Ekonomi Dan Bisnis UMSU}

Kompetensi social dosen mampu memberikan dampak yang kuat dan secara nyata terhadap hasil belajar mahasiswa. Hubungan yang positif juga memberikan makna bahwa ada hubungan yang berbanding lurus antara kompetensi social dosen dengan hasil belajar mahasiswa, artinya semakin baik kompetensi sosial yang dimiliki oleh dosen maka akan semakin baik hasil belajar mahasiswa S-1 FEB UMSU Medan.

Hasil penelitian ini sesuai dengan penelitian yang dilakukan oleh Irianto (2015), yaitu seorang dosen dituntut memiliki kemampuan untuk hidup berdampingan dengan baik bersama orang lain dalam hal ini adalah peserta didiknya. Dosen sebagai tenaga pendidik 
diharapkan mampu memberikan contoh teladan yang baik bagi mahasiswa, terhadap lingkungannya dalam menjalankan hak dan kewajibannya sebagai bagian dari masyarakat sekitar (Ayusri juniantari, 2017)

\section{PENUTUP}

\section{Kesimpulan}

Kompetensi pedagogic, kompetensi professional, kompetensi pribadi dan kompetensi social terbukti berkorelasi positif signifikan terhadap hasil belajar mahasiswa. Seluruh kompetensi yang dimiliki dosen memiliki dampak secara nyata dan kuat untuk mempengaruhi hasil belajar mahasiswa. Semakin baik kompetensi dosen dalam mengajar maka akan memberikan pengaruh yang positif mampu meningkatkan hasil belajar mahasiswa, sebaliknya jika dosen memiliki kompetensi yang rendahakan berdampak pada hasil belajar mahasiswa yang rendah juga.

\section{Saran}

Dosen harus memahami bahwa proses pendidikan tidak hanya sekedar mengajar atau memberikan materi tetapi lebih luas yaitu tentang mendidik mahasiswa secara menyeluruh sehingga ada peningkatan hasil belajar secara IQ dan EQ mahasiswa. Dosen juga membutuhkan proses komunikasi yang baik serta menjadi contoh teladan yang baik bagi mahasiswanya sehing ga dosen mampu menjadi professional yang bertanggungjawab terhadap profesinya sebagai pengajar/pendidik. Tidak hanya itu dosen juga harus bersikap objektif dalam penilaian, tidak bersikap diskriminatif sehingga mahasiswa akan lebih menghargai dosen. Fakultas juga memiliki peran penting untuk melakukan kendali dan pengawasan terhadap seluruh praktek pembelajaran yang dilakukan oleh dosen sebagai gambaran kontribusi kompetensi dosen, sehingga fakultas juga turut mengawasi seluruh kompetensi dosen FEB UMSU demi kualitas pembelajaran yang baik.

\section{DAFTAR PUSTAKA}

Ayusrijuniantari, I. (2017). Pentingnya Peningkatan Kompetensi Guru Dalam Pencapaian Hasil Belajar Siswa, (March). Retrievedfrom https://www.researchgate.net/publicat ion/315099985\%0APENTINGNYA

Irianto. (2015). Pengaruh Kompetensi Pedagogik, Profesional, Kepribadian Dan Sosial Yang Dimilki Dosen Terhadap Hasil Belajar Mahasiswa (Studi Empiris Pada StiieAmm Mataram). Jurnal Bisnis Dan Kewirausahaan, 11(1), 46-58.

Putri, S. D., \&Suwatno. (2017). Pengaruh Kompetensi Pedagogik Dan Kompetensi Sosial Terhadap Prestasi Belajar Siswa Pada Mata Pelajaran Pengantar Administrasi Perkantoran Kelas X AdministrasiPerkantoran Di Smk Negeri 1 Subang. JurnalPendidikan Manajemen Perkantoran, 1(1), 918. 
Sarbaini, S. (2017). Kompetensi Kepribadian, Kompetensi Sosial dan Prestasi Belajar Siswa di Kabuparten Tanah Laut. Banjarmasin: Jaringan Penelitian Bappeda Kabupaten Tanah Laut.

Tahrir. (2013). Pengaruh Kompetensi Dosen Terhadap Motivasi Belajar Pada Mahasiswa Fakultas Psikologi Uin " Sgd" Bandung. Jurnal Ilmiah Psikologi, 6(1), 756-765.

Sugiyono. (2011). Metode Penelitian Kuantitatif, kualitatif dan R\&D. Bandung: Alfabeta. 